\title{
PROGRAMMED REPRODUCTION IN SHEEP OUTSIDE THE MATING SEASON
}

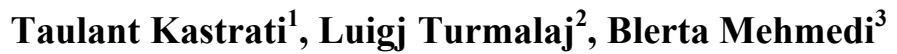 \\ ${ }^{1}$ Practical Veterinary, Kosovo. \\ ${ }^{2}$ University of Tirana, Veterinary Medicine Faculty, Albania \\ ${ }^{3}$ University of Prishtine, Faculty of Agriculture and Veterinary, \\ Boulevard "Bill Clinton" nn., 10000 Prishtina, Kosovo \\ kastratitaulant@yahoo.com//turmalajluigj@yahoo.com.//blertamehmedi@uni-pr.edu
}

\begin{abstract}
The ewes follow the seasonal reproductive pattern which in the climate conditions of Kosovo means that the sexual activity is manifested from June to August. We assessed the efficiency of two hormonal protocols for the oestrus synchronization in ewes out of the sexual season (during March-April 2012). For this reason two experimental groups, each comprised of 50 Sharr breed ewes, are formed. The both groups had the same breeding and physiological status (all are over 60 days after parturition) as well as management conditions. The treatment for the first group was comprised of progestagen vaginal sponge insertion (Fluor Geston Acetate, $40 \mathrm{mg}$, Intervet $\AA$ ) for 14 days and the $500 \mathrm{IU}$ of eCG (equine Chorionic Gonadotropin), Foligon (Intervet $\left.{ }^{\circledR}\right), \mathrm{i} / \mathrm{m}$ were applied at the time of vaginal sponge removal. The second group followed the similar protocol, but they were additionally treated with $0.1 \mathrm{mg} / \mathrm{ewe}$ gonadotropin releasing hormone (GnRH; Fertagyl, Intervet $\left.{ }^{\Omega}\right) 36 \mathrm{~h}$ after the eCG application. The oestrus was detected by presentation of the ewes to ram $48 \mathrm{~h}$ after the vaginal device was removed. The presented ewes were mated twice in the interval of 12 hours. From the data of the study we have the rate that induced oestrus for the both groups was 94 $\%$ and $96 \%$ respectively $(\mathrm{P}>0.05)$. We believe that combining hormonal treatment following an accurate methodology delivers very good results in inducing and synchronizing the estrus out of the mating season in sheep.
\end{abstract}

Key words: oestrus detection; mated; out of season; oestrus synchronization

\section{ПРОГРАМИРАНА РЕПРОДУКЦИЈА КАЈ ОВЦИ НАДВОР ОД СЕЗОНАТА НА ПАРЕЊЕ}

Овците следат сезонски репродуктивна шема, што во климатските услови на Косово значи дека сексуалната активност се манифестира во периодот јуни-август. Ја проценивме ефикасноста на два хормонални протокола за синхронизација на еструс кај овци надвор од сезонта на парење (во текот на мартаприл 2012 година). За таа цел беа формирани две експериментални групи, секоја составена од 50 овци од шарпланинската раса. Двете групи имаа ист начин на одгледување, чување и физиолошки статус (сите беа над 60 дена по породувањето). Третманот за првата група беше составен од прогестаген, вметнат со вагинален сунѓep (Fluor Geston Acetate, $40 \mathrm{mg}$, Intervet ${ }^{\circledR}$ ) за време од 14 дена, а $500 \mathrm{IU}$ на ECG (Equine Chorionic Gonadotropin), Foligon (Intervet $\mathbb{R}$ ) беа применети i/m при отстранувањето на вагиналниот сунѓер. Втората група го следеше сличниот протокол, но овците дополнително беа третирани со $0,1 \mathrm{mg} /$ овца гонадотропин ослободувачки хормон (GnRH; Fertagyl, Intervet (®) 36 часа по примената на ECG. Еструсот кај овците беше детектиран со помош на овни пробачи 48 часа по отстранувањето на вагиналните песарии. Селектираните овци беа осеменети два пати, во интервал од 12 часа. Од податоците во студијата се гледа дека процентот на индуциран еструс кај двете групи изнесуваше $94 \%$ и 96\%, соодветно (р>0.05). Веруваме дека комбинирањето на хормоналниот третман по точна методологија обезбедува многу добри резултати во поттикнување и синхронизација на еструсот надвор од сезоната на парење кај овците.

Клучни зборови: откривање на еструс; спарени; надвор од сезона; синхронизација на еструс

\section{INTRODUCTION}

Sheep are considered species with seasonal sexual activity. Depending on geographical location, this activity is different (photoperiod). In terms of Kosovo, the period of sexual activity is during the months from June to August. The period of sexual inactivity (deep anoestrus) appears in the months from January to March. Advanced studies on the reproductive physiology of sheep 
have shown that sexual activity can be promoted through hormonal treatments outside the breeding season. Sheep after calving fall in the state of seasonal anoestrus or lactation. The rate of anoestrus depends on many factors such as the state of health, nutrition, report light / dark in the bow of 24 hours (photoperiod), suckling, male factor, milk production, etc. (Scaramuzzi et al., 1999; Sulo 1990). Pregnancy Corpus Luteum in sheep degrades before calving (Beghelli, 1992; Bartlewski et al., 1999). This means that sheep ovaries after calving have neither CL as a source of progesterone nor antral follicle as a source of estrogens. Consequently, in the circulating blood of the sheep we miss both of these hormones that are necessary to promote the hypothalamus to produce GnRH (Youngquist 1997; Skaramuzzi et al., 1999; Skinner et al., 2002). The absence of GnRH, causes the pituitary gland not to HFS and HL. During anoestrus period, follicular kinetics (inactive follicle genesis), is limited. Small follicles grow in the ovaries in a diameter up to $5 \mathrm{~mm}$, which later regress (Bartlewski et al., 1998). This ovarian process is prompted mainly by local growth factors. The process repeats several times until environmental factors, management and hormonal management are "accepted" by biology of the heat cycle in sheep (Caraty et al., 2002; Mori et al., 1998). Interference from outside with synthetic hormones such as progesterone, PMSG and GnRH, stimulates the axis of hypothalamus-pituitary glandovary in favour of activating the reproductive processes outside the mating season (Intervet, 2002; Miller et al., 1998; Ozbej et al., 2001). The biological core of the hormonal treatment of sheep outside the mating season is, in ability of the vaginal device relieve progesterone (artificial CL) and stimulates the hypothalamus and pituitary gland to produce HFS and HL. (Bonanno et al., 1997, Biba et al., 2004; Degl'Inocennti et al., 1992; Beghelli 1992; Evans et al., 2004).

\section{MATERIAL AND METHODS}

This study was conducted in terms of the climate in Peja and Decan Region, Kosovo. For this purpose we selected the sheep breed "Sharri", of 2-6 years old. Sheep are about 60 days after calving and without suckling. The physiological status of the ovaries was determined by ultrasound we measured and the metabolic status via the blood glucose level. Sheep were held in equal husbandry conditions (food, water, space). The hormonal treatment was conducted according to the experiment groups.

The first group (50 head) had this hormonal treatment:

- Day 1 (morning). Placement of the tampon into the vagina (Fluorine-Geston-acetate, $40 \mathrm{mg}$ ).

- Day 14 (morning). Removal of the vaginal tampon and the injection of PMSG (Foligon), 500 UI, i / m.

Day 16 (morning). Detection of heat and controlled individual mating (natural).

The sheep in the second group (50 head), in addition to the above treatment were treated with GnRH, $0.1 \mathrm{mg}$ (Fertagyl), 36 hours after the PMSG injection. For the realization of copulation 10 rams of the same breed with optimal health condition were selected. The rams were also examinated. Mating was carried out by respecting a normal load up to 5 sheep per ram, mating from one to another with a20 minutes break. Mating was done twice a day with a 12 hour interval.

Study aims: firstly, to evaluate the degree of stimulation and synchronization of heat in sheep during deep anoestrus, with the help of hormonal factor (FGA + PMSG) and secondly, to assess the degree of fertility and fertility for both schemes of hormonal treatment (FGA + FGA + PMSG \& $\mathrm{PMSG}+\mathrm{GnRH})$. The last issue will be published at another time.

\section{RESULTS AND DISCUSSION}

The main directions of the study focused on assessing the ovary activity of sheep outside the reproductive season, through ultrasound (deep anoestrus), for metabolic status, by measuring the level of glucose in blood, the degree of stimulation and synchronization of heat and for the degree of fertility and fertility lambs with two methods of hormonal treatment.

\section{Ovarian activity during deep anoestrus in experimented sheep}

From ultrasound images obtained from a survey in experimented sheep, show that "Follicular Kinetics' is present outside the mating season. However, the diameter of follicles varies from 2-5 $\mathrm{mm}$. These follicles can not produce the right amount of estrogens to promote the cycle (Bartlewski 
et al., 1998; McNilly et al., 1991; Broers, 1996; Beghelli, 1992). Not reaching maturity and then ovulation or luteinisation of follicles, makes you miss the source of progesterone, the hormonal factor more important for sexual activity (Driancourt et al., 1997; Scaramuzzi et al., 1998).

In terms of metabolic status, concentrated attention is towards the level of glucose in the blood. It should be emphasized that without a normal metabolic bed, hormonal treatment outcomes remain low (Nagatani et al., 2000; Breadford et al., 1999; Bartlewski et al., 1999; Blache et al., 2000). The obtained data is presented in Table 1.

\section{Table 1}

Precentage of glucose in experimented sheep

\begin{tabular}{lcc}
\hline \hline Groups & $\begin{array}{c}\text { Heads Average precentage } \\
\mathrm{mg} / \%\end{array}$ \\
\hline First group (FGA+PMSG) & 50 & $50.6 \pm 2.27$ \\
Second group (FGA+PMSG+GnRH) & 50 & $53.9 \pm 2.00$ \\
\hline \hline
\end{tabular}

The data shows that the concentration of glucose in the blood is normal and indicates an optimal metabolic status in terms of energy level. According to Chagas \& Blanche, the assessment of the reproductive condition of the sheep through the "glucose hypothesis" remains an alternative valid prognostic in the practice of OVIN reproduction.

As for indicators of stimulation and synchronization of heat, the use of two synthetic hormones from outside (progesterone and PMSG), has an aim to stimulate the sexual activity in the treated sheep. Two groups have an equal treatment in terms of stimulating the heat. The data is presented in Table 2.

Coming into heat and simultaneous mating of sheep in both groups (95\%), shows a high efficiency of the hormonal system in the study (Domingues 1998). The combined action of progesterone and PMSG, have stimulated heat "natural" and fertility. These results were helped by the presence of ovarian follicular kinetics in experimented sheep.

Table 2

The rate of stimulation and synchronization of heat through hormonal treatment

\begin{tabular}{llcccc}
\hline \hline \multirow{2}{*}{ Groups and heads } & \multirow{2}{*}{ Treatment } & \multicolumn{2}{c}{ Acceptance of mating after PMSG } & The rate of \\
& & 48 hours & 60 hours & 72 hours & $\begin{array}{c}\text { stimulation } \\
\%\end{array}$ \\
\hline Firts (50) & (FGA+PMSG) & 50 & 48 & - & $94 \%$ \\
Second (50) & (FGA+PMSG+GnRH) & 50 & 50 & - & $96 \%$ \\
\hline \hline
\end{tabular}

\section{CONCLUSIONS}

In terms of Kosovo, the sheep during deep anoestrus (March-April), result with a ovarian activity. Through ultrasound in sheep ovaries follicles with Ø 2-5 mm were found.

The concentration of glucose in the blood varies from $50.6 \pm 2.27 \mathrm{mg} / \%$ in the first group to $53.9 \pm 2: 00 \mathrm{mg} / \%$, in the second group $(\mathrm{P}<005)$. This can be taken as an indicator of health and welfare of the sheep before hormonal treatment.

Methodical treatment of sheep in deep anoestrus with the system "two valent" (FGA + PMSG), or "three-valent" (FGA + PMSG + GnRH), stimulates heat in $95 \%$ of treated head.

\section{REFERENCES}

[1] Bartlewski, M. P,, Beard, P. A,, Cook, J. S., Rawling, C. N., (1998): Ovarian follicular dynamics during anoestrus in eëes. Journal Reproduction and Fertility. 113, 275285.

[2] Bartlewski, M. P., Beard, P. A., Cook, J. S., Honaramooza, A., Rawling, C. N., (1999): Ovarian antral follicular dynamics and their relationship ëith endocrine variables throughout the oestrous cycle in breeds of sheep differing in profilificacy. Journal Reproduction and Fertility. 115, 111-124.

[3] Beghelli, V. (1992): Regolazione endocrina dell'attivita riproduttiva nella pecora e nella capra, Associazione Nazionale dalla pastorizia. Perugia, 37-50.

[4] Blache, D., Chagas, M. L., Blackberry, A. M., Vercoe E. Ph., Martin, B. G. (2000): Metabolic factors affecting the reproductive axis in male sheep. Journal Reproduction and Fertility. 120, 1-11. 
[5] Biba, N., Sulo, Xh., Turmalaj, L., Degl'Innocenti, S., Polisca, A., Di Salvo, P., "Implementazione della conoscenza tecnico-scientifiche nel settore della riproduzione animale con particolare riferimento alle specie ovina e caprina. Progietto, FMV, Perugia - FMV, Tirane. 20022004.

[6] Bonanno, A., Grigoli, A., Portolano, B., Todaro M. (1997): Effects of treatament with Fluor-Gestone-Acetate (FGA) and Pregnant Mare Serum Gonadotropine (PMSG) for oestrus indication and synchronization on the quality of milk products from Comisana ewes. Scienza $e$ Tecnica Lattiero Casearia. 48, 111-132.

[7] Broers, P. (1996): La riproduzione nell'ovino". In: Compendio di Riproduzione Animale. Intervet. 97-123.

[8] Caraty, A., Delaleu, B., Chesneau, D., Fabre-Nys, C. (2002): Sequental role of $E_{2}$ and $G n R H$ for the expression of estrous behavior in ewes. Endocrinology. 143 (1), 139-145.

[9] Degl'Innocenti, S., Carnevali, F., Polisca, A., Sargenti, M. (1986): Comporazione tra tre diversi metodi di inuzione e sincronizzione degli estri nella pecora sarda. Il Vergaro, $5,21-24$.

[10] Driancourt, A. M. (1995): Ovulation rate: Control mechanisms and manipulation. In: IXth International Conference on Production Diseases, in Farm Animals. September 11-14 1995, Free University of Berlin.

[11] Ginther, J. O., et al. (2000): Mechanism of follicle deviation in monovular farm species. Animal Reproduction Science. 58. 197-213.

[12] Evans, O. C. A. 2004: Pattern and manipulation of follicle development in sheep and goats. 55-th annual meeting. Slovenia; 1-10.

[13] Maracek, I., Krajnickova, M., Kostecky, M., Gresarova, G., Valocky, I. (2002): Tertiary follicular growth wave dynamics after oestrus synchronization and superovulation in ewes and goats. Animal Physiology. 71, 481-486.

[14] Intervet. "CRONO-GEST" per induzione e la sincronizationenell specie ovine e caprine". Milano. 2002.

[15] McNeilly, S. A., Picton, M. H., Cambell, K. B., Baird T. D. (1991): Gonadotrophic control of follicle growth in ewes. Journal of Reproduction and Fertility. 43, 259265.

[16] Miller, W. D., Blache, D. (1998): Control metabolic messengers and the effects of nutrition on gonadotrophin secretion in sheep. Journal of Reproduktion and Fertility. $112,347-356$.

[17] Mori, J. (1998): Hormones of reproduction in farm animals: Basic and practical advances. Kitasoto University. 45-55.

[18] Ozbej, O., Tatli, P. (2001): The effects of oestrous synchronization and flushing on reproduction of Awassi ewes. VETCD, 19; 109-115.

[19] Scaramuzzi, J. R., Downing, A. J. (1999): Effect of progesterone on the GnRH-induced secretion of estradiol and androstenedion from the autotransplanted ovary of the anoestrous ewes. Journal of Reproduction and Fertility, 123, 269-280.

[20] Skinner, C. D., Cilliers, D. S., Skinner, D. J. (2002): Effect of ram introduction on the oestrous cycle of springbok ewes, Reproduction. 124; 509-513.

[21] Sulo, Xh. (1990): Animal Reproduction and Theier Pathology, 1, 145-150.

[22] Youngquist, R. S. (1997). Induction of fertile oestrus in ewes during the anestrous or transitional periode. In: Current Therapy in Large Animal Theriogenology, 573, 607$611 .$. 